\title{
NF-KB, stem cells and breast cancer: the links get stronger
}

\author{
Kateryna Shostakand Alain Chariot*
}

\begin{abstract}
Self-renewing breast cancer stem cells are key actors

in perpetuating tumour existence and in treatment

resistance and relapse. The molecular pathways

required for their maintenance are starting to be

elucidated. Among them is the transcription factor

$N F-k B$, which is known to play critical roles in cell

survival, inflammation and immunity. Recent studies

indicate that mammary epithelial NF-KB regulates the

self-renewal of breast cancer stem cells in a model of

Her2-dependent tumourigenesis. We will describe here

the NF-KB-activating pathways that are involved in this

process and in which progenitor cells this transcription

factor is actually activated.
\end{abstract}

Breast cancer is a heterogeneous disease, yet it remains possible to highlight common molecular signatures from distinct tumour subtypes. A frequent feature found in most breast cancer tumours is the constitutive activation of NF- $\mathrm{kB}$, a family of transcription factors that play critical roles in cell survival, proliferation, inflammation and immunity [1]. Deregulated NF- $\mathrm{kB}$ activation results in the persistent nuclear localization of proteins such as p50, p52, p65, cRel and RelB, which leads to the disruption of the balance between cell proliferation and death through the upregulation of anti-apoptotic proteins [2].

\section{The main NF-KB-activating pathways}

Two major NF-kB-activating pathways have been characterized, referred to as the classical or canonical and the alternative or non-canonical pathways. Both rely on the signal-induced phosphorylation and degradation of an inhibitory molecule and the subsequent release and nuclear shuttling of NF-kB proteins. Yet, both pathways

*Correspondence: Alain.chariot@ulg.ac.be

Interdisciplinary Cluster for Applied Genoproteomics (GIGA-Research), Unit of Medical Chemistry and GIGA-Signal Transduction, University of Liege, CHU, Sart-Tilman, 4000 Liège, Belgium differ by the signals that trigger them as well as by the identity of the activated kinases, the inhibitory molecule and the NF- $\mathrm{kB}$ proteins. The classical pathway is typically triggered by pro-inflammatory cytokines such as TNF $\alpha$ or IL- $1 \beta$ and ultimately leads to the degradation of the inhibitory molecule ІкB $\alpha$ by the NF-кB essential modulator (NEMO)/ІкB kinase (IKK) $\gamma$-containing IKK complex through a TAK1-dependent pathway [1] (Figure 1). The p50/p65 heterodimer will then move into the nucleus to induce the expression of genes involved in cell proliferation and survival, inflammation and innate immunity. The alternative pathway triggers the partial degradation of the inhibitory molecule p100 into p52 through a NF- $\mathrm{kB}$-inducing kinase (NIK)-dependent pathway (Figure 1). This cascade relies on an IKKa heterodimer but not on NEMO/IKK $\gamma$ and ultimately leads to the nuclear shuttling of $\mathrm{p} 52 / \mathrm{RelB}$ dimers. This signalling pathway plays a critical role in adaptive immunity [1].

\section{The classical NF-KB-activating pathway in breast cancer}

Based on the key role of NF- $\mathrm{kB}$ in mammary epithelial proliferation, architecture and branching during early post-natal development $[3,4]$, it was not surprising to see that the constitutive NF- $\mathrm{KB}$ activation found in several breast tumour cell lines has profound consequences in the initiation and progression of breast cancer [5]. NF- $\mathrm{KB}$ is mostly activated in oestrogen receptor-negative (ERnegative) and ErbB2-positive tumours [6,7]. Importantly, a NEMO-binding domain (NBD) peptide, which acts as a selective inhibitor of the IKK complex, blocked heregulinmediated NF- $\mathrm{KB}$ activation and induced apoptosis preferentially in proliferating cells, showing that the classical pathway largely contributes to tumour development [6]. Those initial reports were followed by studies that more specifically addressed the role of NF- $\mathrm{kB}$ in breast tumour development in vivo. A genetic approach in which the classical NF- $\mathrm{kB}$-activating pathway is inhibited in defined windows during polyoma middle $\mathrm{T}$ oncogene (PyVT) tumourigenesis showed that interfering with this pathway increases tumour latency and decreases tumour burden [8]. These findings are in agreement with data showing the requirement of $\mathrm{NF}-\mathrm{kB}$ for the induction and 


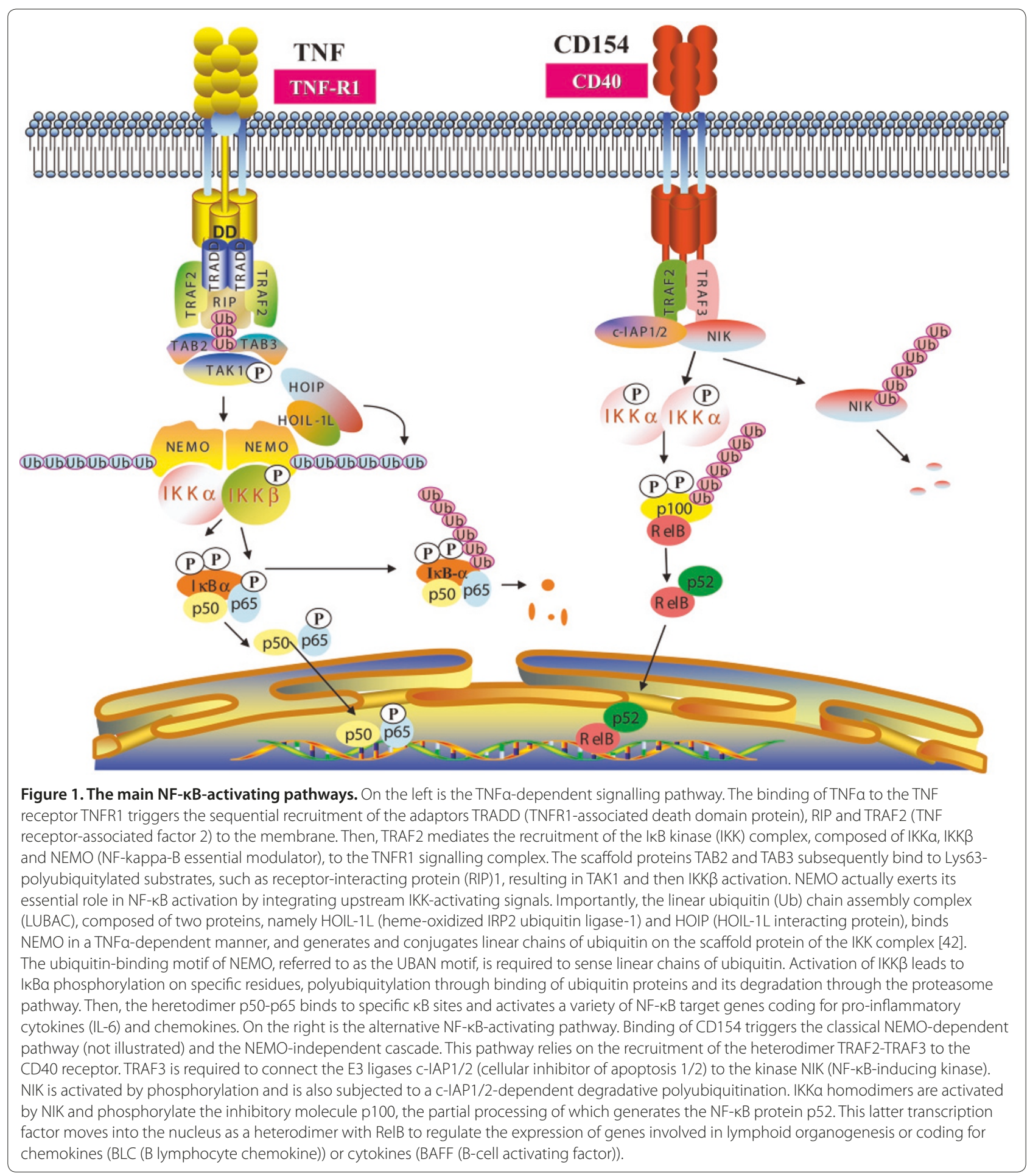

maintenance of the epithelial-mesenchymal transition (EMT), a process that critically controls breast cancer progression $[9,10]$. Indeed, the MCF10A immortalized cell line, which is derived from normal mammary epithelial cells, undergoes EMT when overexpressing the $\mathrm{NF}-\mathrm{kB}$ protein $\mathrm{p} 65$. This latter protein suppresses the expression of epithelial markers such as E-cadherin and desmoplakin but also induces the expression of mesenchymal markers such as vimentin. This process may occur through the NF- $\mathrm{kB}$-dependent expression of ZEB-1/ZFHX1A and ZEB-2/ZFHX1B/Smad-interacting protein (SIP1), two transcriptional regulators known to 
repress E-cadherin expression and to promote EMT [10]. These data strongly suggest that NF- $\mathrm{KB}$ regulates breast tumour progression independently of its effects on mammary development.

\section{The alternative NF-KB-activating pathway in breast cancer}

The classical NF-kB-activating pathway is not the only one that contributes to breast cancer development. Indeed, early studies also demonstrated enhanced expression of the NF- $\mathrm{kB}$ protein $\mathrm{p} 52$ in breast cancer samples [11,12]. Moreover, increased p52/RelB activity was also observed in mouse mammary tumours induced by 7,12-dimethylbenz $(a)$ anthracene (DMBA) [13]. The definitive proof that the alternative NF- $\mathrm{kB}$-activating pathway is involved in breast cancer development came from the phenotype of a mouse transgenic model in which $\mathrm{p} 100 / \mathrm{p} 52$ is specifically overexpressed in the mammary epithelium by using the $\beta$-lactoglobulin milk protein promoter [14]. This mouse model not only showed a delay in mammary development but also a transient reduction in ductal branching during pregnancy. Matrix metalloproteinase (Mmp)-2, Mmp-9 and cyclooxygenase (Cox)-2 turned out to be overexpressed in these transgenic mice. Constitutive p100 overexpression causes an aberrant phenotype, as shown by the thickening of primary ducts, loss of epithelial cell organization and small areas of hyperplastic growth. Finally, an increase in p100/p52 expression was also observed in PyVT mice when tumour development is observed [14]. Importantly, no change of nuclear p65 was detected in this mouse model, suggesting that the phenotype observed was exclusively the result of a deregulated alternative NF- $\mathrm{kB}$-activating pathway. The expression of the NF- $\kappa B$ protein RelB, which is known to play a critical role in this signalling cascade, is increased in ER $\alpha$ negative breast cancer cells [15]. ER $\alpha$ actually represses NF- $\kappa B$ and AP-1 activities and consequently RelB expression. Interestingly, RelB is required for the maintenance of the mesenchymal phenotype of ER $\alpha$-negative Hs578T breast cancer cells, at least in part through the transcriptional induction of BCL2 [15].

\section{Other NF-KB-activating pathways in breast cancer}

$N F-\kappa B$ is not exclusively activated through the TNF family of receptors. Indeed, the binding of epidermal growth factor (EGF) to its receptor (EGFR) also ultimately activates NF- $\mathrm{kB}$ and most likely contributes to the enhanced activity of this transcription factor in ERnegative breast cancer cells [16]. The exact mechanism by which EGF activates NF- $\mathrm{kB}$ in breast cancer cells remains unclear but may be similar to that described in lung cancer cells. EGF appears to trigger ІкB $\alpha$ phosphorylation on tyrosine 42 through an IKK-independent pathway
[17]. Of note, the inhibitory molecule ABIN-1 also negatively regulates EGF-mediated NF- $\mathrm{KB}$ activation, a pathway that requires its carboxy-terminal ubiquitinbinding domain [18].

The IKK complex is not the only one whose activation is often constitutive in breast cancer. Indeed, the so called IKK-related kinase IKKe is also overexpressed in some cases of breast adenocarcinomas as the result of the 1q32 amplicon [19]. This gene amplification is not the only mechanism by which this kinase is aberrantly expressed, as more than $45 \%$ of IKKE-overexpressing breast carcinomas do not harbour the 1q32 amplicon. IKK $\varepsilon$ expression can be induced by casein kinase 2 (CK2) in breast cancer cells [20] and other pathways still to be characterized may also contribute to this phenomenon. Interestingly, this kinase is known to promote type I interferon gene induction through IRF3 phosphorylation, acts downstream of Akt and activates NF-KB by facilitating the nuclear localization of c-REL $[19,20]$. Importantly, all $\mathrm{IKK} \varepsilon$ substrates identified in breast cancer samples so far act as signalling molecules in $\mathrm{NF}-\mathrm{kB}$-dependent cascades and mediate the oncogenic potential of this IKK-related kinase. CYLD, a NF-kB inhibitor acting as a tumour suppressor, is phosphorylated by $\mathrm{IKK} \varepsilon$, a modification that decreases its deubiquitine ligase activity and consequently its inhibitory potential [21]. Therefore, an extensive understanding of the role of NF- $\mathrm{kB}$ in breast cancer development and progression should not be limited to the characterization of both classical and alternative pathways.

\section{NF-KB and cancer stem cells}

Self-renewing breast cancer stem cells are the subject of intensive research as key actors responsible for perpetuating tumour existence and for treatment resistance and relapse. These cells can be isolated by virtue of their expression of the cell surface markers epithelial-specific antigen (ESA) and CD44 and the absence of expression of CD24. The expression of aldehyde dehydrogenase has also been used to enrich for tumour-initiating cells and revealed that distinct breast cancers may contain cancer stem cells that harbour different cell surface markers $[22,23]$. Importantly, stem cell properties can also be gained by transformed cells undergoing EMT [24].

At the molecular level, Wnt, Notch and Hedgehog developmental pathways control the self-renewal of normal stem cells and also appear to be deregulated in many human breast cancers [25]. Moreover, the membrane bound receptor tyrosine kinase Her2, which is overexpressed in $30 \%$ of breast cancers, also critically controls the cancer stem-cell population [26]. As Her2 activates NF- $\mathrm{kB}$ through the canonical pathway [27], the hypothesis that this latter family of proteins may be involved in the biology of breast cancer stem cells made 
sense. This issue was recently addressed in a mouse model of Her2 breast tumourigenesis in which NF-kB was temporally suppressed in the mammary gland [28]. This approach was elegant as NF-kB activation through the canonical pathway was only suppressed in mammary epithelial cells but not in inflammatory cells, blood vessels or adipocytes, where this transcription factor most likely contributes to tumour development. Moreover, NF- $\mathrm{B}$ B suppression was inducible to circumvent the requirement of this transcription factor in normal ductal development. The authors first noticed that NF-kB is required for cell proliferation and colony formation of Her2-derived murine mammary tumour cell lines [28]. They subsequently observed that NF- $\mathrm{kB}$ governs the rate of initiation of Her2 tumours through multiple pathways ranging from reactive oxygen species production to cellular proliferation, invasion, inflammation and vasculogenesis. Mammary epithelial NF- $\mathrm{kB}$ contributed to the recruitment of tumour-associated macrophages. Interestingly, the proportion of CD44-positive cells dramatically decreased in Her2-dependent tumours where NF-kB was suppressed, thus indicating that this transcription factor maintains progenitor cell expansion [28]. This result was further supported by the reduced formation of non-adherent mammospheres with cell lines derived from Her2-dependent tumours in which $\mathrm{NF}-\mathrm{\kappa B}$ was inhibited. This phenomenon was potentially due to the reduced expression of key embryonic stem cell regulators such as Sox2 and Nanog [28]. As this study was based on the expression of an I $\mathrm{B} B \alpha$ super repressor in which both serines 32 and 36 were mutated to alanines, the resulting phenotype was caused by a defective NF- $\kappa B$ and IKK $\beta$-dependent activating pathway. Yet, this signalling cascade is not the only one that contributes to breast cancer stem cell expansion. Indeed, IKK $\alpha^{\mathrm{AA} / \mathrm{AA}}$ knockin mice in which IKK $\alpha$ activation is disrupted by replacement of activation loop serines by alanines showed delayed tumour development when crossed with the Her2 murine breast cancer model [29]. Breast cancer cells from these mice generated primary but not secondary mammospheres, suggesting that $\mathrm{IKK} \alpha$ is also required for the self-renewal of tumour-initiating cells from the Her2 breast cancer model.

IKK $\alpha$ appears to act as a central NF- $\mathrm{KB}$-activating protein in the self-renewal of breast cancer stem cells, as evidenced by data obtained from additional mouse models of breast cancer. Indeed, deletion of IKK $\alpha$ in mammary-gland epithelial cells affects the onset of progestin-driven breast cancer [30]. This kinase is actually activated through the Receptor activator of nuclear factor kappa-B ligand (RANKL)/RANK pathway when progesterone or synthetic derivatives (progestins) such as medroxyprogesterone acetate (MPA) are given in combination with the DNA-damaging agent DMBA to mice. As a result, cell proliferation occurs through cyclin D1 gene induction [30]. Interestingly, treatment with MPA alone led to a significant expansion of luminal progenitor cells through a massive induction of RANKL, a phenomenon that was impaired in females defective for RANK. Mouse mammary tumour virus (MMTV)-RANK transgenic mice showed an enhanced susceptibility to mammary tumours following a MPA/DMBA treatment whereas RANK invalidation in the mammary gland resulted in a delayed onset and decreased incidence of progestin-driven breast cancers [30,31]. Importantly, breast cancer cells from MPA and DMBA-treated RANKdefective mice formed primary but not secondary mammospheres, strongly suggesting that a loss of RANK expression markedly impairs the self-renewal capacity of cancer stem cells [30].

NF- $k \mathrm{~B}$ appears to be activated during differentiation of the mammary colony-forming cells in which luminal progenitor cells can be found [32] (Figure 2). On the other hand, the mammary stem-like basally located cells, also known as mammary repopulating units, are devoid of NF- $\kappa$ B activity [32,33].

As a transcription factor required for the production of chemokines and cytokines, NF- $\mathrm{k}$ B has been defined as an essential actor in the link between inflammation and oncogenesis initiation and progression [34]. Indeed, inflammatory molecules such as IL6 provide growth signals that promote malignant cell proliferation. Interestingly, a transient activation of the kinase oncoprotein Src in MCF10A cells results in phenotypic transformation that includes the formation of multiple foci, the ability to form colonies in soft agar and tumours in xenografts as well as mammosphere formation [35]. This epigenetic switch, defined when a stable cell type changes into another stable cell type without any modification in DNA sequences, involves a rapid inflammation response that requires NF-kB [35]. More specifically, NF- $\mathrm{kB}$ activation triggers $\operatorname{Lin} 28 B$ expression, which in turn decreases Let-7 microRNA levels. As Let-7 microRNA directly targets IL6 mRNAs by binding their 3' untranslated region, the IL6-dependent signalling pathways are strongly induced through the Src- and NF-kBdependent cascade [35]. This newly defined pathway appears to play a key role in the self-renewal capacity of breast cancer stem cells. Therefore, this study not only defined Src as an oncogenic kinase that promotes the expansion of breast cancer stem cells but also demonstrated how critical NF- $\mathrm{KB}$ is in this process.

\section{Unclear issues}

Despite significant progress in the elucidation of the roles played by NF-kB in breast cancer stem cell expansion, some issues remain to be experimentally addressed. The gene candidates known to regulate embryonic stem cells 


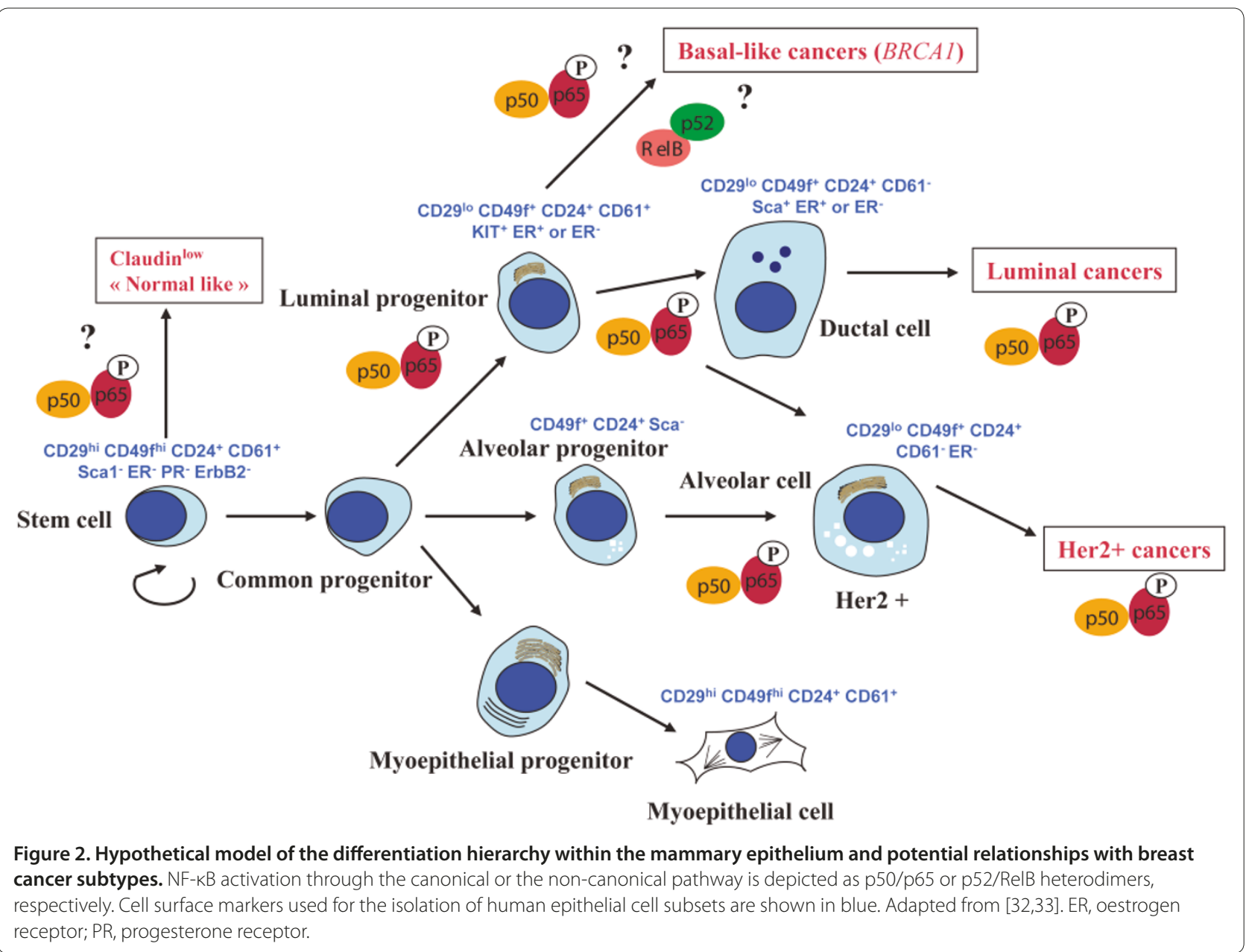

and to be specifically induced through IKK $\alpha$ activation in the mammary gland remain to be identified. Are Sox2 and Nanog induced by both IKK $\alpha$ and IKK $\beta$ ? Cyclin D1, whose expression is strongly impaired in the IKK $\alpha^{\mathrm{AA} / \mathrm{AA}}$ knockin mouse [4], may be one promising candidate as its kinase activity appears to be crucial for the selfrenewal of mammary stem and progenitor cells [36]. It also remains to be seen whether the alternative pathway is truly involved in breast cancer stem cell expansion. Based on the fact that the Her-2-dependent NF- $\mathrm{BB}$ activation pathway surprisingly relies on IKK $\alpha$ but not on IKK $\beta$ [27], the phenotype observed in the IKK $\alpha^{\mathrm{AA} / \mathrm{AA}}$ knockin mouse crossed with the Her2 breast cancer model may actually be the result of a defective classical rather than alternative $\mathrm{NF}-\mathrm{\kappa B}$ activation cascade. In agreement with this hypothesis, the IKK $\alpha^{\mathrm{AA} / \mathrm{AA}}$ mutation in mammary epithelial cells results in decreased nuclear levels of p50 and p65, the proteins acting in the classical pathway.

Most of the data showing a link between NF- $\mathrm{kB}$ and breast cancer stem cells were obtained using the Her-2 tumour model, which classifies with human luminal-type breast cancers. The canonical NF- $\mathrm{B}$ pathway is active in normal luminal progenitor cells and is consequently required for the formation of mammary epithelial tumours [32]. On the other hand, NF- $\mathrm{kB}$ appears to be dispensable for tumour development and progression in the MMTV-Wnt1 model, which classifies with human basal-like breast cancers [29]. This is most likely due to the absence of nuclear p65 in these lesions as well as in the mammary stem-like basally located cells, also referred to as mammary repopulating units [32]. The molecular mechanisms underlying the specific NF-kB activation in luminal progenitor cells remains to be elucidated. The following years will provide further insights into the biology of both multipotent stem cells and lineage-committed progenitor cells and will tell us why and how NF- $\mathrm{KB}$ regulates their functions.

The IKK-related kinase IKKe appears to act as an oncogenic protein through NF-kB, yet it is totally unclear whether and how this kinase promotes breast cancer stem cell expansion. The generation of a new mouse 
model specifically harbouring the 1q32 amplicon may be useful to address this issue. Recent studies indicated that the IKK complex targets multiple substrates and therefore has additional NF- $\mathrm{kB}$-independent functions in cancer [37]. Whether and how these unexpected roles contribute to breast cancer stem cell maintenance also remains an open question.

Important studies dedicated to the identification of the cell of origin of solid tumours, including breast cancers, have been published [38]. The cell of origin may correspond to the normal tissue stem cell, which can take advantage of its intrinsic self-renewal capacity. A restricted progenitor can, for other malignancies, act as the initiating cell, as reported, for example, for BRCA1associated breast cancers $[39,40]$. Breast cancers in the BRCA1 mutation carriers have a distinct basal-like phenotype, yet these tumours originated from luminal epithelial progenitors instead of from basal stem cells $[39,40]$. It remains to be seen whether and how NF-kB would be required for the conversion of a luminal progenitor cell to a basal gene expression profile in tumours originated in BRCA1 mutation carriers. Nevertheless, identification of the cell origin is a key step to develop preventive therapeutic approaches in order to suppress or reverse the initial phase of the disease. In this context, the identification of the RANKL/RANK/IKK $\alpha /$ $\mathrm{NF}-\mathrm{kB}$ axis as a key pathway that provides paracrine signals to stem cells means that it is conceivable to prevent some cases of breast cancers by driving stem cells into a dormant state. This strategy could be achieved by interfering with the RANK pathway with some specific inhibitors, some of which are already in clinical trials for bone metastasis [38].

An extensive knowledge of the biology of breast cancer stem cells is also crucial in order to better understand why some patients develop resistance to therapy such as Her2-targeting agents. Resistance to these drugs is the result of various somatic mutations that ultimately trigger aberrant phosphoinositide 3-kinase (PI3K)/Akt activation [41]. Although Akt appears to be dispensable for Her2mediated NF- $\mathrm{kB}$ activation in breast cancer cells [27], this transcription factor is nevertheless a key actor in chemoresistance. Future studies should also tell us whether and how NF-kB inhibition in breast cancer stem cells modulates their resistance to therapy.

\section{Abbreviations}

DMBA, 7,12-dimethylbenz(a)anthracene; EGF, epidermal growth factor; EMT, epithelial-mesenchymal transition; ER, oestrogen receptor; IKK, IKB kinase; IL, interleukin; MMTV, mouse mammary tumour virus; MPA, medroxyprogesterone acetate ; NEMO, NF-kappa-B essential modulator; NF, nuclear factor; NIK, NF-kB-inducing kinase; PyVT, polyoma middle T oncogene; RANK, Receptor activator of nuclear factor kappa-B; RANKL, Receptor activator of nuclear factor kappa-B ligand; RIP, receptor-interacting protein; TNF, tumour necrosis factor.
Competing interests

The authors declare that they have no competing interests.

Published: 26 July 2011

\section{References}

1. Hayden MS, Ghosh S: Shared principles in NF-kappa B signaling. Cell 2008, 132:344-362.

2. Karin M, Lin A: NF-kappa B at the crossroads of life and death. Nat Immunol 2002, 3:221-227.

3. Brantley DM, Chen CL, Muraoka RS, Bushdid PB, Bradberry JL, Kittrell F, Medina D, Matrisian LA, Kerr LD, Yull FE: Nuclear factor-kB (NF-kB) regulates proliferation and branching in mouse mammary epithelium. Mol Biol Cell 2001, 12:1445-1455.

4. Cao YX, Bonizzi G, Seagroves TN, Greten FR, Johnson R, Schmidt EV, Karin M: IKK alpha provides an essential link between RANK signaling and cyclin D1 expression during mammary gland development. Cell 2001, 107:763-775.

5. Sovak MA, Bellas RE, Kim DW, Zanieski GJ, Rogers AE, Traish AM, Sonenshein GE: Aberrant nuclear factor-kappa B/Rel expression and the pathogenesis of breast cancer. J Clin Invest 1997, 100:2952-2960.

6. Biswas DK, Shi Q, Baily S, Strickland I, Ghosh S, Pardee AB, Iglehart JD: NF-kB activation in human breast cancer specimens and its role in cell proliferation and apoptosis. Proc Natl Acad Sci U S A 2004, 101:10137-10142.

7. Nakshatri H, BhatNakshatri P, Martin DA, Goulet RJ, Sledge GW: Constitutive activation of NF-kappa B during progression of breast cancer to hormoneindependent growth. Mol Cell Biol 1997, 17:3629-3639.

8. Connelly L, Barham W, Onishko HM, Sherrill T, Chodosh LA, Blackwell TS, Yull FE: Inhibition of NF-kappa B activity in mammary epithelium increases tumor latency and decreases tumor burden. Oncogene 2011, 30:1402-1412.

9. Huber MA, Azoitei N, Baumann B, Grunert S, Sommer A, Pehamberger H, Kraut N, Beug H, Wirth T: NF-kappa B is essential for epithelialmesenchymal transition and metastasis in a model of breast cancer progression. J Clin Invest 2004, 114:569-581.

10. Chua HL, Bhat-Nakshatri P, Clare SE, Morimiya A, Badve S, Nakshatri H: NF-kappa B represses E-cadherin expression and enhances epithelial to mesenchymal transition of mammary epithelial cells: potential involvement of ZEB-1 and ZEB-2. Oncogene 2007, 26:711-724.

11. Dejardin E, Bonizzi G, Bellahcene A, Castronovo V, Merville MP, Bours V: Highly-expressed P100/P52 (Nfkb2) sequesters other Nf-Kappa-B-related proteins in the cytoplasm of human breast-cancer cells. Oncogene 1995, 11:1835-1841.

12. Cogswell PC, Guttridge DC, Funkhouser WK, Baldwin AS: Selective activation of NF-kappa B subunits in human breast cancer: potential roles for NF-kappa B2/p52 and for Bcl-3. Oncogene 2000, 19:1123-1131.

13. Demicco EG, Kavanagh KT, Romieu-Mourez R, Wang XB, Shin SR, LandesmanBollag E, Seldin DC, Sonenshein GE: RelB/p52 NF-kappa B complexes rescue an early delay in mammary gland development in transgenic mice with targeted superrepressor I kappa B-alpha expression and promote carcinogenesis of the mammary gland. Mol Cell Biol 2005, 25:10136-10147.

14. Connelly L, Robinson-Benion C, Chont M, Saint-Jean L, Li HJ, Polosukhin V, Blackwell TS, Yull FE: A transgenic model reveals important roles for the NF-kappa B alternative pathway (p100/p52) in mammary development and links to tumorigenesis. J Biol Chem 2007, 282:10028-10035.

15. Wang XB, Belguise K, Kersual N, Kirsch KH, Mineva ND, Galtier F, Chalbos D, Sonenshein GE: Oestrogen signalling inhibits invasive phenotype by repressing RelB and its target BCL2. Nat Cell Biol 2007, 9:470-U197.

16. Biswas DK, Cruz AP, Gansberger E, Pardee AB: Epidermal growth factorinduced nuclear factor kappa B activation: A major pathway of cell-cycle progression in estrogen-receptor negative breast cancer cells. Proc Natl Acad Sci U S A 2000, 97:8542-8547.

17. Sethi G, Ahn KS, Chaturvedi MM, Aggarwal BB: Epidermal growth factor (EGF) activates nuclear factor-kappa B through I kappa B alpha kinaseindependent but EGF receptor-kinase dependent tyrosine 42 phosphorylation of I kappa B alpha. Oncogene 2007, 26:7324-7332.

18. Huang L, Verstrepen L, Heyninck K, Wullaert A, Revets H, De Baetselier P, Beyaert R: ABINs inhibit EGF receptor-mediated NF-kappa B activation and growth of EGF receptor-overexpressing tumour cells. Oncogene 2008, 27:6131-6140.

19. Boehm JS, Zhao JJ, Yao J, Kim SY, Firestein R, Dunn IF, Sjostrom SK, Garraway LA, Weremowicz S, Richardson AL, Greulich H, Stewart CJ, Mulvey LA, Shen 
RR, Ambrogio L, Hirozane-Kishikawa T, Hill DE, Vidal M, Meyerson M, Grenier JK, Hinkle G, Root DE, Roberts TM, Lander ES, Polyak K, Hahn WC: Integrative genomic approaches identify IKBKE as a breast cancer oncogene. Cell 2007, 129:1065-1079.

20. Eddy SF, Guo SQ, Demicco EG, Romieu-Mourez R, Landesman-Borag E, Seldin DC, Sonenshein GE: Inducible I kappa B kinase/I kappa B kinase epsilon expression is induced by CK2 and promotes aberrant nuclear factor-kappa B activation in breast cancer cells. Cancer Res 2005, 65:11375-11383.

21. Hutti JE, Shen RR, Abbott DW, Zhou AY, Sprott KM, Asara JM, Hahn WC, Cantley LC: Phosphorylation of the tumor suppressor CYLD by the breast cancer oncogene IKK epsilon promotes cell transformation. Mol Cell 2009, 34:461-472.

22. Ginestier C, Hur MH, Charafe-Jauffret E, Monville F, Dutcher J, Brown M, Jacquemier J, Viens P, Kleer CG, Liu S, Schott A, Hayes D, Birnbaum D, Wicha MS, Dontu G: ALDH1 is a marker of normal and malignant human mammary stem cells and a predictor of poor clinical outcome. Cell Stem Cell 2007, 1:555-567.

23. Charafe-Jauffret E, Ginestier C, lovino F, Wicinski J, Cervera N, Finetti P, Hur MH, Diebel ME, Monville F, Dutcher J, Brown M, Viens P, Xerri L, Bertucci F, Stassi G, Dontu G, Birnbaum D, Wicha MS: Breast cancer cell lines contain functional cancer stem cells with metastatic capacity and a distinct molecular signature. Cancer Res 2009, 69:1302-1313.

24. Mani SA, Guo W, Liao MJ, Eaton EN, Ayyanan A, Zhou AY, Brooks M, Reinhard F, Zhang CC, Shipitsin M, Campbell LL, Polyak K, Brisken C, Yang J, Weinberg RA: The epithelial-mesenchymal transition generates cells with properties of stem cells. Cell 2008, 133:704-715.

25. Liu SL, Dontu G, Wicha MS: Mammary stem cells, self-renewal pathways, and carcinogenesis. Breast Cancer Res 2005, 7:86-95.

26. Korkaya H, Paulson A, lovino F, Wicha MS: HER2 regulates the mammary stem/progenitor cell population driving tumorigenesis and invasion. Oncogene 2008, 27:6120-6130.

27. Merkhofer EC, Cogswell P, Baldwin AS: Her2 activates NF-kappa B and induces invasion through the canonical pathway involving IKK alpha. Oncogene 2010, 29:1238-1248.

28. Liu M, Sakamaki T, Casimiro MC, Willmarth NE, Quong AA, Ju X, Ojeifo J, Jiao X, Yeow WS, Katiyar S, Shirley LA, Joyce D, Lisanti MP, Albanese C, Pestell RG: The canonical NF-kappa B pathway governs mammary tumorigenesis in transgenic mice and tumor stem cell expansion. Cancer Res 2010, 70:10464-10473.

29. Cao YX, Luo JL, Karin M: I kappa B kinase a kinase activity is required for self-renewal of ErbB2/Her2-transformed mammary tumor-initiating cells. Proc Natl Acad SciU S A 2007, 104:15852-15857.

30. Schramek D, Leibbrandt A, SigI V, Kenner L, Pospisilik JA, Lee HJ, Hanada R, Joshi PA, Aliprantis A, Glimcher L, Pasparakis M, Khokha R, Ormandy CJ, Widschwendter M, Schett G, Penninger JM: Osteoclast differentiation factor
RANKL controls development of progestin-driven mammary cancer. Nature 2010, 468:98-102.

31. Gonzalez-Suarez E, Jacob AP, Jones J, Miller R, Roudier-Meyer MP, Erwert R, Pinkas J, Branstetter D, Dougall WC: RANK ligand mediates progestininduced mammary epithelial proliferation and carcinogenesis. Nature 2010, 468:103-107.

32. Pratt MAC, Tibbo E, Robertson SJ, Jansson D, Hurst K, Perez-Iratxeta C, Lau R, Niu MY: The canonical NF-kappa B pathway is required for formation of luminal mammary neoplasias and is activated in the mammary progenitor population. Oncogene 2009, 28:2710-2722.

33. Visvader JE: Keeping abreast of the mammary epithelial hierarchy and breast tumorigenesis. Gene Dev 2009, 23:2563-2577.

34. Naugler WE, Karin M: NF-kappa B and cancer - identifying targets and mechanisms. Curr Opin Genet Dev 2008, 18:19-26.

35. Iliopoulos D, Hirsch HA, Struhl K: An epigenetic switch involving NF-kappa B, Lin28, Let-7 microRNA, and IL6 links inflammation to cell transformation. Cell 2009, 139:693-706.

36. Jeselsohn R, Brown NE, Arendt L, Klebba I, Hu MG, Kuperwasser C, Hinds PW: Cyclin D1 kinase activity is required for the self-renewal of mammary stem and progenitor cells that are targets of MMTV-ErbB2 tumorigenesis. Cancer Cell 2010, 17:65-76.

37. Chariot A: The NF-kappa B-independent functions of IKK subunits in immunity and cancer. Trends Cell Biol 2009, 19:404-413.

38. Visvader JE: Cells of origin in cancer. Nature 2011, 469:314-322.

39. Lim E, Vaillant F, Wu D, Forrest NC, Pal B, Hart AH, Asselin-Labat ML, Gyorki DE, Ward T, Partanen A, Feleppa F, Huschtscha LI, Thorne HJ; kConFab, Fox SB, Yan M, French JD, Brown MA, Smyth GK, Visvader JE, Lindeman GJ: Aberrant luminal progenitors as the candidate target population for basal tumor development in BRCA1 mutation carriers. Nat Med 2009, 15:907-913.

40. Molyneux G, Geyer FC, Magnay FA, McCarthy A, Kendrick H, Natrajan R, Mackay A, Grigoriadis A, Tutt A, Ashworth A, Reis-Filho JS, Smalley MJ: BRCA1 basal-like breast cancers originate from luminal epithelial progenitors and not from basal stem cells. Cell Stem Cell 2010, 7:403-417.

41. Nagata Y, Lan KH, Zhou X, Tan M, Esteva FJ, Sahin AA, Klos KS, Li P, Monia BP, Nguyen NT, Hortobagyi GN, Hung MC, Yu D: PTEN activation contributes to tumor inhibition by trastuzumab, and loss of PTEN predicts trastuzumab resistance in patients. Cancer Cell 2004, 6:117-127.

42. Iwai K, Tokunaga F: Linear polyubiquitination: a new regulator of NF-kappa B activation. EMBO Rep 2009, 10:706-713.

doi:10.1186/bcr2886

Cite this article as: Shostak K, Chariot A: NF-KB, stem cells and breast cancer: the links get stronger. Breast Cancer Research 2011, 13:214. 